\title{
Randomized Placebo-Controlled Trial of Guava Juice as a Source of Ascorbic Acid to Reduce Iron Deficiency in Tarahumara Indigenous Schoolchildren of Northern Mexico
}

Joel Monárrez-Espino, MD, PhD, Mardia López-Alarcón, MD, PhD, Ted Greiner, PhD

Mexican Institute of Social Security, Clinical Epidemiology Research Unit, Chihuahua (J.M.-E.), Mexican Institute of Social Security, Medical Nutrition Research Unit, Mexico City (M.L.-A.), MÉXICO, Department of Food and Nutrition, College of Human Ecology, Hanyang University, Seoul (T.G.), KOREA

Key words: ascorbic acid, guava, indigenous, iron deficiency anemia, Mexico, schoolchildren, Tarahumara, vitamin C, iron, randomized controlled trial

Objective: Assess the efficacy of a 10-week consumption of guava juice on the iron status of children with mild iron deficiency anemia.

Methods: Ninety-five boarding school children aged 6-9 years identified as anemic were randomly allocated to receive $300 \mathrm{~mL}$ of natural guava juice containing $\sim 200 \mathrm{mg}$ of ascorbic acid (AA) or placebo (guava-flavored juice free of AA) with the main meal ( $5 \mathrm{~d} / \mathrm{wk}$ ). Information about dietary intake was collected at weeks 3, 5, and 7 at school and household levels. Changes in hemoglobin ( $\mathrm{Hb})$ and plasma ferritin (PF) among the subsample iron deficient at baseline $(n=33)$ were the main outcomes.

Results: Iron and phytic acid intakes at school and at home did not differ between groups. Baseline $\mathrm{Hb}$ and $\mathrm{PF}$ were $11.9 \pm 0.5 \mathrm{~g} / \mathrm{dL}$ and $8.2 \pm 3.6 \mathrm{ng} / \mathrm{mL}$ for the guava, and $11.4 \pm 1.1 \mathrm{~g} / \mathrm{dL}$ and $7.4 \pm 4.6 \mathrm{ng} / \mathrm{mL}$ for the placebo group (Hb: $p=0.08$; PF: $p=0.31$ ); at week 10 of the study, corresponding values were $13.1 \pm 0.9 \mathrm{~g} / \mathrm{dL}$ and $17.9 \pm$ $10.3 \mathrm{ng} / \mathrm{mL}(\mathrm{n}=16)$, and $12.3 \pm 1.3 \mathrm{~g} / \mathrm{dL}$ and $15.4 \pm 5.8 \mathrm{ng} / \mathrm{mL}(\mathrm{n}=12)(\mathrm{Hb}: p=0.05 ; \mathrm{PF}: p=0.21)$. With analysis of variance (ANOVA) for repeated measures, the guava group had $0.64 \mathrm{~g} / \mathrm{dL}$ higher $\mathrm{Hb}\left(\mathrm{CI}_{95}, 0.18-1.11 ; p\right.$ $=0.01)$ and $2.47 \mathrm{ng} / \mathrm{mL}$ higher $\mathrm{PF}\left(\mathrm{CI}_{95},-1.04\right.$ to $\left.5.98 ; p=0.12\right)$ compared with the placebo group.

Conclusion: Guava juice providing $200 \mathrm{mg}$ AA at one meal on each school day had a marginal effect on $\mathrm{Hb}$ and PF concentrations in children consuming high-phytate diets fortified with iron.

\section{INTRODUCTION}

Dietary iron absorption is determined by its heme iron (HI) and nonheme iron (NHI) content, by the type and quantity of dietary factors that influence iron absorption, and by the individual's iron status [1]. Whereas $\mathrm{HI}$ is highly bioavailable independent of dietary composition [2], NHI absorption can be as low as $2 \%$, depending on the enhancing or inhibiting effects of food components present in a given meal [3-5]. In rural Mexico, NHI constitutes a very large proportion of the dietary iron consumed, as animal sources of HI are scarce [6,7].
Higher bioavailability of NHI can be achieved by increasing the dietary content of iron absorption enhancers such as vitamin $\mathrm{C}$ or ascorbic acid (AA) [8], fish, and meat [9], or by decreasing the content of inhibitors such as calcium [10,11], phytates [12,13], and polyphenols [14,15].

AA has long been recognized as a powerful enhancer of NHI absorption $[8,16]$, and a dose-effect relationship between AA intake and iron absorption has been documented [17]. The principal mechanisms appear to be reduction of ferric to ferrous iron, which seems to be a requirement for the prevention of formation of insoluble and unabsorbable iron compounds, and

Address reprint requests to: Joel Monárrez-Espino, MD, PhD, Instituto Mexicano del Seguro Social, Unidad de Investigación en Epidemiología Clínica, Grupo de Investigación en Nutrición y Salud Indígena, Avenida Universidad 1101, Colonia Centro, C.P. 31000 Chihuahua, Chihuahua, MÉXICO. E-mail: jmonarrez@hotmail.com Abbreviations: $\mathrm{AA}=$ ascorbic acid, $\mathrm{ANOVA}=$ analysis of variance, $\mathrm{CDI}=\mathrm{Commission}$ for the Development of Indigenous Peoples, $\mathrm{CRP}=\mathrm{C}$-reactive protein, $\mathrm{CV}=$ coefficient of variation, $\mathrm{Hb}=$ hemoglobin, $\mathrm{HI}=$ heme iron, $\mathrm{ID}=$ iron deficiency, $\mathrm{IDA}=$ iron deficiency anemia, $\mathrm{NHI}=$ nonheme iron, $\mathrm{PF}=$ plasma ferritin, $\mathrm{RDA}=$ recommended dietary allowance, $\mathrm{UL}=$ upper limit.

Journal of the American College of Nutrition, Vol. 30, No. 3, 191-200 (2011)

Published by the American College of Nutrition 
uptake of iron into the mucosal cells [18]. In addition, AA counteracts the effects of inhibitors such as phenolic compounds [15], calcium [19], and phytates [13,15].

Several studies have shown the pronounced enhancing effects of added AA on the absorption of dietary NHI when foods or drinks rich in or supplemented with AA were tested [20-23].

AA, natural or synthetic, is a remarkably safe substance [24], even in premature infants [25], as excess intake is excreted. Adverse effects, mostly minor gastrointestinal upset, have been reported, but only with very large doses $(>3-4 \mathrm{~g} / \mathrm{d})$ [26-28]. Renal calcium oxalate stone formation $[29,30]$ and the development of iron overload [31,32] have been dismissed as important concerns related to AA consumption.

Major dietary sources of AA include guava, papaya, mango, citrus fruits, and various berries [33]. Small amounts of AA are present in vegetables such as broccoli, bell peppers, potato, cabbage, tomato, spinach, and cauliflower, but the cooking process destroys it partially or completely, depending on the time and method of food preparation [34]. Currently, the daily recommended dietary allowance (RDA) (and upper limit [UL]) for children aged 4-8 years and 9-13 years is $25 \mathrm{mg}$ (UL 650) and $45 \mathrm{mg}$ (UL 1200), respectively [35].

Guava (Psidium guajava), a fruit with an exceptionally high AA content, grows in tropical/subtropical regions and thrives especially well in Mexico; it is likely native to this region. The AA content depends on the variety $(50-400 \mathrm{mg} / 100 \mathrm{~g})$ and declines by $\sim 50 \mathrm{mg}$ as it hits its peak ripeness; it also decreases with canning and storage [36,37]. Mexican species have 180$240 \mathrm{mg} / 100 \mathrm{~g}$ of AA [38]. Guavas also contain some carotenes (200-400 IU/100 g) and iron $(0.30-0.70 \mathrm{mg} / 100 \mathrm{~g}$ ) [36].

Iron deficiency (ID) has long been recognized as the most common nutritional disorder worldwide and is a major cause of nutritional anemia in children [39]. Anemia is a problem in Tarahumara indigenous schoolchildren of northern Mexico with a prevalence of $\sim 25 \%$ ( $10 \%$ with iron deficiency anemia [IDA]) [40]. Of the strategies devised to tackle ID and IDA [41], food-based interventions have been relatively neglected, in part because of the urgent need to rapidly improve iron and hemoglobin $(\mathrm{Hb})$ status through fortification and supplementation programs, but also because no practical approaches have so far proved successful.

Increased intake of AA is commonly included in nutritional advice to treat and prevent ID/IDA [41-43], but only one long-term community level efficacy trial has examined its impact. This study assessed the effect of administration of $25 \mathrm{mg}$ AA twice daily in the form of limeade with meals for 8 months to nonanemic iron-deficient adult women, and found no improvement in various indicators of iron status [44]. The authors suggested that in diets with high phytic acid content and iron-fortified foods, the ratio of AA to iron would need to be at least 12:1 (by weight) for the AA to have an impact on iron status.
The present randomized controlled trial aimed to assess the efficacy of drinking natural guava juice containing 200 mg of AA with the main meal from Monday through Friday during a 10 -week period on the iron status of indigenous schoolchildren with mild IDA who were consuming a school diet with ironfortified foods and high in phytic acid content.

\section{MATERIALS AND METHODS}

In addition to the children's verbal assent, written informed consent was obtained from parents/tutors. The proposal was approved by the Ethics Committee of Research at the Mexican Institute of Social Security (2005/1/I/029) and by the Mexican Commission for the Development of Indigenous Peoples (CDI) in Chihuahua, the institution under whose aegis the study was conducted. The CDI promotes the educational and nutritional development of indigenous children living in highly marginalized areas with extreme poverty through boarding schools that accommodate 100-150 children, providing free primary education, housing, and food [45].

\section{Study Design}

A school-based efficacy trial with random assignment to receive guava or placebo was conducted to examine the effect of drinking $300 \mathrm{~mL}$ of natural guava juice containing $~ 200 \mathrm{mg}$ of AA with the main meal (midday) for 10 weeks on the $\mathrm{Hb}$ and plasma ferritin (PF) concentrations of indigenous Tarahumara boarding school children with mild IDA.

A total of 38 indigenous boarding schools are located in Guachochi, the most predominantly indigenous municipality of northern Mexico [46]. Four were chosen in consultation with CDI officials to represent the range of socioeconomic and geographic (particularly taking into account altitude differences) variability present in the district, and to provide enough children to fulfill sample size needs. Children attending CDI schools usually come to school on Mondays and return home on Fridays.

From the 519 children registered in the 4 selected schools, 295 aged 6-9 years were screened for mild anemia (capillary $\mathrm{Hb}, 9-11.5 \mathrm{~g} / \mathrm{dL}$ at sea level). A total of 95 anemic children were identified by using altitude-adjusted cutoffs [47], rendering a prevalence of anemia that ranged between $27 \%$ and $42 \%$ among the sampled schools.

The anemic children were randomly allocated into intervention $(n=50)$ or placebo groups $(n=45)$. The efficacy trial focused only on those children with ID at baseline, defined as $\mathrm{PF}<12 \mathrm{ng} / \mathrm{mL}$ corresponding to the fifth percentile of a reference distribution for children aged 6-15 years [48] with normal C-reactive protein (CRP $<10 \mathrm{mg} / \mathrm{dL}$ ) and no history of respiratory or gastrointestinal infection within the 2 weeks preceding blood extraction (Fig. 1). Thirty-three children met these criteria: 17 in the guava group and 16 in 


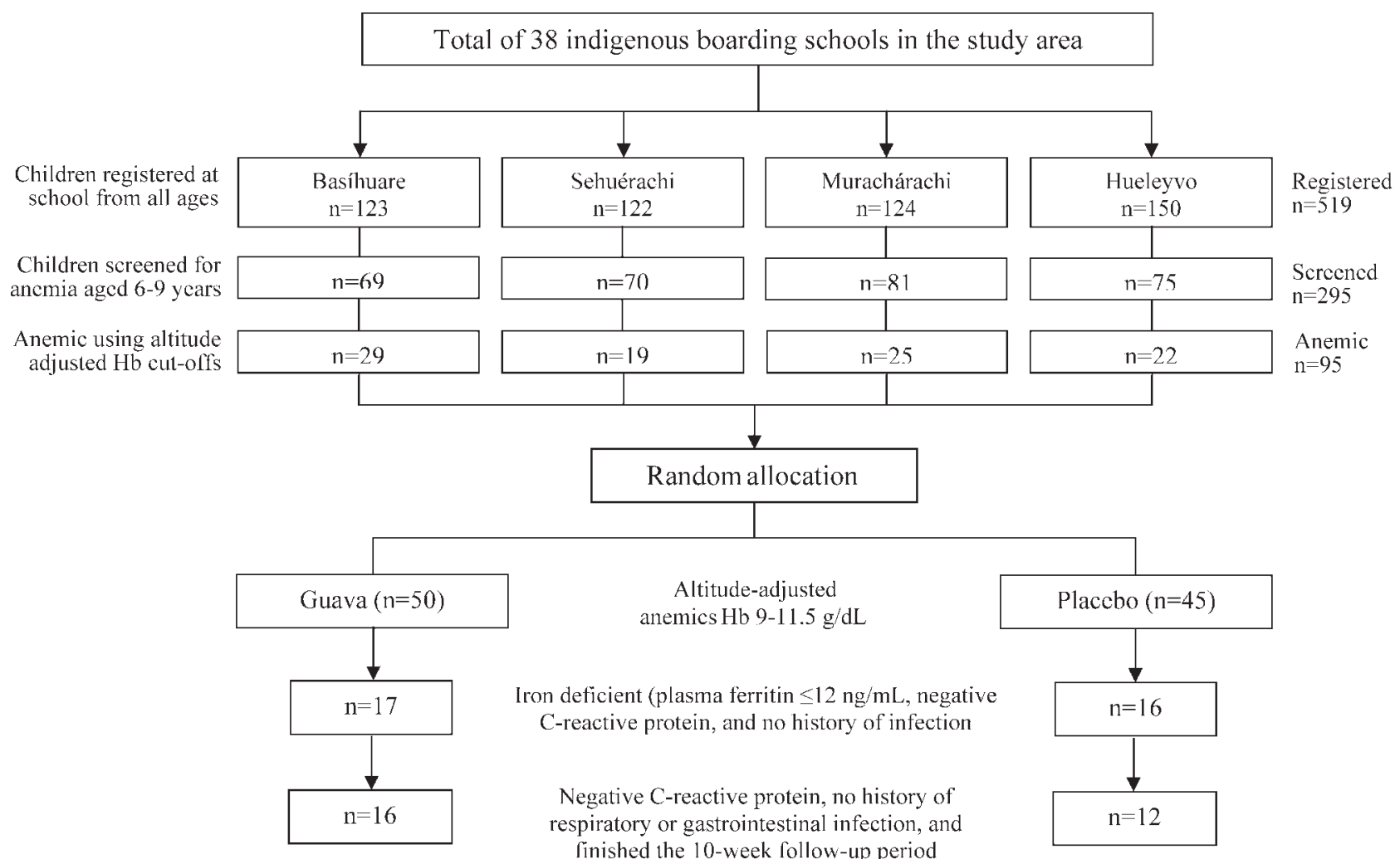

Fig. 1. Selection of children from the 4 boarding schools included in the trial, Sierra Tarahumara, 2006.

the placebo group. Children with moderate or severe anemia $(\mathrm{Hb}<9 \mathrm{~g} / \mathrm{dL})$, those who had received iron supplementation within 3 months before the study, and any who suffered from hematologic or chronic disease were excluded. All children infected with intestinal parasites were given individualized and supervised antiparasitic treatment at the beginning of the study to avoid the chance that parasitic infection might modify the results.

\section{Sample Size}

The sample size estimation was based on the assumed biologically significant increase of $5 \mathrm{ng} / \mathrm{mL}$ in PF concentration [44] in the guava group after 10 weeks, setting an alpha value of 0.05 and a beta value of 0.20. Data on PF to estimate background variability were obtained from a previous study of boarding schoolchildren in the same region [40]. The calculation resulted in a required sample size of 16 children per group. However, because of our inability to screen for PF in a timely fashion in this isolated rural area, mostly because of logistic and financial constraints, we had to enter children into the study on the basis of $\mathrm{Hb}$ levels, as mentioned previously. We then chose a sample size for the total number of schools and the total number of children entering the study based on an estimation of likely IDA levels in this population.

\section{Interventions}

Different types of beverages are drunk with meals at the boarding schools; for breakfast and dinner, the most common are atoles (thick drinks made of cereals), and for lunch, artificial fruit drinks of various flavors are most often provided. Thus, we decided to offer the supplement with the main meal at midday during schooldays (Monday to Friday).

Guava Juice. The AA content of fresh guavas from a batch similar to those used in the trial was determined at 3 maturity levels (pre-ripe, ripe, and post-ripe) at the Department of Food Science and Technology of the National Institute of Nutrition in Mexico City, using atomic absorption spectrometry according to the analytical technique recommended by the Association of Official Analytical Chemists International. The guava juice was prepared by mixing guava, water, and a small amount of sugar in an electric blender, such that a $300 \mathrm{~mL}$ glass provided an overall estimated $200 \mathrm{mg}$ of AA.

Artificial Guava Juice (Placebo). Children in the placebo group were given $300 \mathrm{~mL}$ of artificially flavored guava juice, 
which contained no ascorbic, citric, malic, or other acids that promote iron absorption [49].

\section{Data Collection}

Baseline Data. An individual questionnaire was administered at the beginning of the trial to register child characteristics such as age, school grade, weight, and height. Children were screened for fecal parasites using direct microscopy, and diagnoses were made with at least 1 positive result from 2 serial samples as reported by 2 laboratory technicians; those infected were given individualized and supervised treatment with oral mebendazole for helminths and metronidazole for protozoa before the trial.

Dietary Assessment. The mean daily dietary intake of energy, protein, iron (HI, NHI, fortified), phytic acid, and calcium was calculated using weighed food records [50].

At the boarding school, children receive 3 meals on school days: breakfast (07:00 hours), the midday meal (12:30 hours) and dinner (18:00 hours). The type and quantity of ingredients used by the indigenous female cooks to prepare food recipes and drinks and the mode of preparation (i.e., cooking time, dilution with water, salt added, etc.) were recorded through direct observation. For instance, "sopa de fideo" (noodle soup) was a blend containing a certain quantity (depending on the number of children expected to eat at each meal time) of wheat flour noodles, onions, tomatoes, sunflower oil, bouillon cubes, and salt. After the quantity in grams of each food item used to prepare the mix was recorded, the weight of all foods was summed up, and the proportion of each ingredient was calculated from the total weight. Then the standard food ration served to the children was weighed, and the proportion in grams of each ingredient in the mix estimated. The actual amount of food eaten by each child was adjusted for additional servings and leftovers of foods/drinks using Salter weighing scales with $10 \mathrm{~g}$ precision for solids and measuring cups with milliliter scale divisions for liquids. All 3 meal times were added together, and the daily energy and nutrient content was calculated using the food composition database constructed for all foods used in the schools and households. Assessment of the diet served to children at school is provided in another publication [51].

Complete data were available for a subsample of 31 children of the 95 anemic children (guava 18; placebo 13) for 9 days from 3 nonconsecutive weeks (Tuesday, Wednesday, and Thursday of weeks 3, 5, and 7). Mondays were excluded, as many children arrived to the boarding school by noon, and Fridays, because most left for home after the midday meal.

The dietary intake at the household was assessed using 48hour recall questionnaires administered to a subsample of 22 mothers of participating children (guava 13; placebo 9). They were interviewed Monday mornings about what children ate or drank over the previous weekend, including foods utilized, preparation methods, and meal times. Mothers were asked about the quantities of food prepared and offered to and consumed by the child using both traditional and volumetric measures, which were later converted into net weight or volume for data analyses. The questions were translated into Rarámuri, the indigenous language, for those who did not speak Spanish. Direct observations at indigenous households were carried out to record traditional food preparations, including the staples, maize tortillas, and beans. Daily nutrient intake calculations were similar to those at school, but were based on 6 days from 3 nonconsecutive weekends (Saturday and Sunday of weeks 3, 5, and 7).

Dietary data were collected by nutritionists trained by the principal investigator. They lived at the boarding schools throughout the study period and were responsible to prepare and serve the guava and placebo drinks to the children, and to collect all dietary data at school and household levels.

The food composition was obtained from 3 main sources: (1) the Latin American Food Composition Table [38]; (2) the U.S. Department of Agriculture Nutrient Database for Standard Reference [33]; and (3) the food product labels. Phytate content was mainly estimated using data published by Wyatt and Triana-Tejast from foods commonly consumed in northern Mexico [52], which conform to the staples of the Tarahumara diet in both schools and households.

HI was determined on the basis of iron originating from meat, fish, and poultry; NHI was obtained by summing the iron from all other foods; and fortified iron was calculated from the fortified industrialized products used. Dietary iron density, expressed as milligrams per 1000 kilocalories, was calculated by dividing the total milligrams of iron consumed by the child by the total calories consumed during the day and multiplying the result by 1000 .

The number of days of food intake data needed to calculate intake was 7, and was based on the estimate of energy content, considering a $95 \%$ confidence level, $20 \%$ precision, and a coefficient of variation (CV) for energy of $25 \%$ [53]. In this trial, we used 9 and 6 days for the school and household diets, respectively.

Compliance, Morbidity, and Adverse Effects. A daily registry was used to document the children's school attendance and their ingestion of guava or placebo drinks. A questionnaire was administered on Fridays to document general symptoms, including headache, abdominal pain, nausea, vomiting, malaise, anorexia, dizziness, fever (sublingual temperature $>38^{\circ} \mathrm{C}$ ), and diarrhea (watery stools for $>2$ consecutive days), as possible side effects.

Biochemical Data. At the screening visit, the middle finger of all children at the boarding schools whose parents consented was pricked to obtain a drop of capillary blood for $\mathrm{Hb}$ measurement using a new portable photometer, HemoCue 201+ (HemoCue AB, Ängelholm, Sweden), which performs a self-calibration, requiring no intervention by the operator; the average of 2 consecutive $\mathrm{Hb}$ readings was calculated. 
Anemia was diagnosed on the basis of recommended $\mathrm{Hb}$ cutoff points at sea level (6-11 years: $<11.5 \mathrm{~g} / \mathrm{dL})$ [54] adjusted for altitude [47]. From all who were anemic, nonfasting blood was drawn from the cubital vein of the right arm directly into a 5 $\mathrm{mL}$ vacutainer tube containing $\mathrm{K}_{2}$-EDTA (Becton Dickinson, Franklin Lakes, NJ). The tube was opened, and a drop of blood was collected by capillary action into the microcuvette and placed in the HemoCue 201+ photometer. Hb concentration was determined using the average of 2 consecutive readings. Blood samples then were transported on dry ice for 2-4 hours across unpaved/paved mountain roads to the participating hospital, where plasma was separated by centrifugation at $4500 \mathrm{rpm}$ for 3 minutes, placed in $1.5 \mathrm{~mL}$ Eppendorf tubes, and frozen at $-20^{\circ} \mathrm{C}$ before it was sent to the Nutrition Research Laboratory in Mexico City for PF determination.

PF was quantified using a 2-site solid-phase immunoradiometric assay (IRMA-Mat Ferritin, DiaSorin Inc, Stillwater, $\mathrm{MN}$ ); the coefficient of variation (CV) was $7.2 \%$. C-reactive protein was measured qualitatively by a latex slide test. Positive values were excluded from analyses on the assumption that ferritin levels were thereby elevated as the result of infection or inflammation [55]. $\mathrm{Hb}, \mathrm{PF}$, and CRP were measured at baseline and at the end of follow-up (week 10).

\section{Statistical Analyses}

Statistical procedures were conducted using Minitab statistical software, version 14.5 (Minitab Inc, State College, PA). Guava and placebo groups were compared at baseline with respect to age, sex, weight, height, and parasite infections using Student's $t$-test and Pearson's $\mathrm{Chi}^{2}$ or Fisher's exact test for continuous and categorical data, respectively.

Student's $t$-test and analysis of variance (ANOVA) with Bonferroni tests were used to compare daily dietary energy and nutrient intakes, including iron, AA, and phytic acid, as well as the biochemical parameters $\mathrm{Hb}$ and $\mathrm{PF}$ between groups at baseline and at week 10 .

ANOVA for repeated measurements analysis was used to evaluate changes in $\mathrm{Hb}$ and $\mathrm{PF}$. Mean differences and $95 \%$ confidence intervals are presented; the significance level was set at $p<0.05$.

Microsoft Office Excel (Microsoft Corporation, Redmond, WA) was used to calculate dietary intake, and data were analyzed using the Statistical Package for the Social Sciences (SPSS) computer software, version 14.0 (SPSS Inc, Chicago, IL).

\section{RESULTS}

\section{Baseline Characteristics}

The amount of AA found to be in the guava juice varied, depending on ripeness (pre-ripe 184.7, ripe 319.9, post-ripe $115.5 \mathrm{mg} / 100 \mathrm{~g}$ flesh). Overall, based on our estimation of how ripe the guavas used tended to be, and accounting for an estimated $5 \%$ loss due to processing, we calculate that the children received an average of about $200 \mathrm{mg} / 300 \mathrm{~mL}$ drink offered at the midday meals.

Baseline characteristics of ID children stratified by treatment group are presented in Table 1. All variables, including mean BMI and BMI percentile, were very similar between the guava and placebo groups. The mean number of days that children received guava (45.2 days of 50 total possible days in 10 weeks; $90.5 \%$ ) or placebo (46.8 days; $93.6 \%)$ during the 10 -week period was also similar $(p>0.05)$.

\section{Adverse Effects}

The number of children who presented with fever (median 0 , range $0-3$ for both groups) or diarrhea (median 0 , range $0-5$ for guava; and median 0, range $0-4$ for placebo) was comparable between groups. Headache, stomachache, and malaise accounted for $84 \%$ of these potential side effects, but no differences were noted between groups. Mild abdominal pain was the most common side effect that could potentially be attributed to ingestion of AA; it was reported by 3 of the 16 children in the experimental group and by 2 of the 12 children in the placebo group during the trial.

\section{Dietary Intake}

A comparison of the intake of selected nutrients between the guava and placebo groups at boarding school and household

Table 1. Comparison of Baseline Characteristics of Schoolchildren in the Guava and Placebo Groups, Sierra Tarahumara, 2006

\begin{tabular}{lccc}
\hline \multicolumn{1}{c}{ Variable $^{\mathrm{a}}$} & $\begin{array}{c}\text { Guava } \\
(\mathrm{n}=17)\end{array}$ & $\begin{array}{c}\text { Placebo } \\
(\mathrm{n}=16)\end{array}$ & $p$ Value $^{\mathrm{b}}$ \\
\hline Weight, $\mathrm{kg}$ & $21.3 \pm 2.9$ & $21.3 \pm 4.7$ & 0.97 \\
Height, cm & $116.8 \pm 6.2$ & $116.1 \pm 11.2$ & 0.82 \\
Body mass index, $\mathrm{kg} / \mathrm{m}^{2}$ & $15.6 \pm 1.5$ & $15.6 \pm 0.95$ & 0.94 \\
Body mass index, & & & \\
$\quad$ percentile & & & \\
Age, y & $45.5 \pm 30.6$ & $48.0 \pm 20.9$ & 0.78 \\
Sex, \% & $7.2 \pm 1.1$ & $6.8 \pm 1.4$ & 0.34 \\
$\quad$ Male & & & \\
$\quad$ Female & 52.9 & 62.5 & 0.72 \\
School year, \% & 47.1 & 37.5 & \\
$\quad$ Preschool-first & 47.1 & & \\
$\quad$ Second-third & 52.9 & 43.3 & 0.73 \\
Parasite infection, \% & & & \\
$\quad$ Yes & & & \\
$\quad$ No & 58.8 & 50.0 & 0.73 \\
\hline
\end{tabular}

${ }^{\mathrm{a}}$ Mean $\pm \mathrm{SD}$ for continuous and percentages for categorical variables.

b Student's $t$-test for continuous and Pearson/Fisher testing for categorical variables.

${ }^{\mathrm{c}}$ Computed using the Centers for Disease Control and Prevention (CDC) online BMI percentile calculator for children.

${ }^{\mathrm{d}}$ Presence of Entamoeba histolyticaldispar, Giardia lamblia, or Ascaris lumbricoides. 
Table 2. Comparison of Dietary Intake of Selected Nutrients at Boarding School and Household Levels in Schoolchildren Receiving Guava (Experimental Group) or Placebo, Sierra Tarahumara, 2006*

\begin{tabular}{|c|c|c|c|c|c|c|}
\hline \multirow[b]{2}{*}{ Nutrient } & \multicolumn{3}{|c|}{ Boarding School ${ }^{1}$} & \multicolumn{3}{|c|}{ Household $^{2}$} \\
\hline & $\begin{array}{l}\text { Experimental }^{3} \\
\quad(\mathrm{n}=18)\end{array}$ & $\begin{array}{l}\text { Placebo } \\
(\mathrm{n}=13)\end{array}$ & $\begin{array}{c}\text { Total } \\
(\mathrm{n}=31)\end{array}$ & $\begin{array}{l}\text { Experimental } \\
\quad(\mathrm{n}=13)\end{array}$ & $\begin{array}{l}\text { Placebo } \\
(\mathrm{n}=9)\end{array}$ & $\begin{array}{c}\text { Total } \\
(\mathrm{n}=22)\end{array}$ \\
\hline Energy, kcal & $2048 \pm 184$ & $1987 \pm 268$ & $2023 \pm 221$ & $1307 \pm 203$ & $1318 \pm 173$ & $1311 \pm 203$ \\
\hline Protein, $g$ & $78 \pm 9$ & $73 \pm 11$ & $77 \pm 10$ & $47 \pm 13.9$ & $47 \pm 9.0$ & $47 \pm 14.0$ \\
\hline Iron, mg & $25.2 \pm 2.7$ & $23.9 \pm 4.0$ & $24.7 \pm 3.3$ & $19.1 \pm 1.7$ & $20.4 \pm 2.6$ & $19.4 \pm 2.4$ \\
\hline Heme & $0.76 \pm 0.1^{\mathrm{a}}$ & $0.67 \pm 0.1^{\mathrm{b}}$ & $0.72 \pm 0.1$ & $0.12 \pm 0.0$ & $0.14 \pm 0.0$ & $0.13 \pm 0.0$ \\
\hline Nonheme & $8.0 \pm 1.1$ & $7.2 \pm 1.3$ & $7.7 \pm 1.3$ & $17.8 \pm 1.7$ & $19.0 \pm 2.8$ & $18.4 \pm 2.1$ \\
\hline Fortified & $16.4 \pm 1.6$ & $15.9 \pm 2.8$ & $16.2 \pm 2.1$ & $1.2 \pm 0.5$ & $1.3 \pm 0.5$ & $1.2 \pm 0.5$ \\
\hline Iron density ${ }^{4}$ & $12.3 \pm 0.42$ & $11.9 \pm 0.51$ & $12.1 \pm 4.8$ & $14.9 \pm 2.7$ & $15.3 \pm 1.9$ & $15.0 \pm 2.4$ \\
\hline Phytic acid, mg & $3010 \pm 610$ & $3069 \pm 651$ & $3045 \pm 631$ & $3286 \pm 846$ & $2690 \pm 1018$ & $2920 \pm 975$ \\
\hline Calcium, mg & $1184 \pm 96$ & $1165 \pm 154$ & $1177 \pm 122$ & $732 \pm 214$ & $770 \pm 117$ & $746.7 \pm 181$ \\
\hline Ascorbic acid, mg & $97 \pm 17$ & $88 \pm 22$ & $93.7 \pm 20.0$ & $62 \pm 31$ & $49 \pm 22$ & $57.6 \pm 28.3$ \\
\hline
\end{tabular}

* One-way ANOVA and Bonferroni tests: different superscript letters $(\mathrm{a}, \mathrm{b})$ indicate statistical significance $(p<0.05)$ between experimental and placebo groups in the boarding school and the household.

${ }^{1}$ Mean daily intake for 9 days (Tuesdays, Wednesdays, and Thursdays from weeks 3, 5, and 7) based on weighing.

${ }^{2}$ Mean daily intake for 6 days (Saturdays and Sundays from weeks 3, 5, and 7) based on recall.

${ }^{3}$ Does not include the $200 \mathrm{mg}$ of AA and $0.5 \mathrm{mg}$ iron contained in the guava juice.

${ }^{4}$ Dietary iron density in $\mathrm{mg} / 1000 \mathrm{kcal}=($ daily iron intake in $\mathrm{mg} /$ daily energy intake in kcal $) \times 1000 \mathrm{kcal}$.

levels is presented in Table 2. For both groups, the boarding school diet provided a mean caloric intake that was approximately $700 \mathrm{kcal}$ higher. Thus protein intake was $60 \%$ greater, and iron intake $5 \mathrm{mg}$ superior to the home diet. However, iron density was $3.2 \mathrm{mg} / 1000 \mathrm{kcal}$ higher at the household level (15.3 vs 12.1; $p<0.01$ ), although it was similar between groups in both the school and the house. Excluding the supplement, intakes of AA were also $56 \%$ higher at school than at home in the guava group and $79 \%$ higher in the placebo group. The guava group consumed slightly more HI when at school. However, no other differences in caloric or nutrient intake were seen between the guava and placebo groups. Intakes of phytic acid were $\sim 3 \mathrm{~g} / \mathrm{d}$ irrespective of group or location.

\section{Biochemical Results}

Blood specimens were available for 17 guava and 16 placebo children at baseline, but only 16 and 12 children, respectively, were eligible to be included in the final analysis. Five children were thus excluded: 3 because of positive CRP (1 guava and 2 placebo), and 2 (placebo) because plasma was not available at the end of the trial (children were not present during the week of blood sampling).

The mean venous $\mathrm{Hb}$ and $\mathrm{PF}$ at baseline and at week 10 were not different between guava and placebo groups. Also, increments of $\mathrm{Hb}$ (guava 1.1, placebo $0.9 \mathrm{~g} / \mathrm{dL} ; p=0.26$ ) and $\mathrm{PF}$ (guava 9.6, placebo $7.9 \mathrm{ng} / \mathrm{mL} ; p=0.32$ ) from baseline to week 10 did not reach statistical significance between groups (Table 3).

However, after individual variability was controlled by use of ANOVA for repeat measures, a significant difference in the increment of $\mathrm{Hb}$ was observed. Venous $\mathrm{Hb}$ increased by 0.65 $\mathrm{g} / \mathrm{dL}\left(95 \%\right.$ confidence interval $\left[\mathrm{CI}_{95}\right], 0.18-1.11 ; p=0.01$ ) more in the guava than in the placebo group. PF also increased by $2.47 \mathrm{ng} / \mathrm{mL}$, following the same trend, but statistical significance was not achieved $\left(\mathrm{CI}_{95},-1.04\right.$ to $\left.5.98 ; p=0.12\right)$.

\section{DISCUSSION}

We conducted a placebo-controlled efficacy trial to determine the effects of drinking natural guava juice containing $\sim 200 \mathrm{mg}$ of AA with the main meal 5 days per week for 10

Table 3. Venous Hemoglobin and Plasma Ferritin of Schoolchildren with Mild Iron Deficiency Anemia at Baseline and Week 10 in the Guava and Placebo Groups, Sierra Tarahumara

\begin{tabular}{|c|c|c|c|}
\hline \multirow[b]{2}{*}{ Measurement } & \multicolumn{3}{|c|}{ Mean \pm SD (n) } \\
\hline & Guava & Placebo & $p^{*}$ \\
\hline \multicolumn{4}{|l|}{ Hemoglobin, g/dL ${ }^{1}$} \\
\hline Baseline & $11.9 \pm 0.5(17)$ & $11.4 \pm 1.1(16)$ & 0.085 \\
\hline Week 10 & $13.1 \pm 0.9(16)$ & $12.3 \pm 1.3(12)$ & 0.055 \\
\hline$\Delta$ week 10 -baseline & $1.1 \pm 0.9(16)$ & $0.9 \pm 1.0(12)$ & 0.265 \\
\hline \multicolumn{4}{|c|}{ Plasma ferritin, $\mathrm{ng} / \mathrm{mL}^{2}$} \\
\hline Baseline & $8.2 \pm 3.6(16)$ & $7.4 \pm 4.6(12)$ & 0.316 \\
\hline Week 10 & $17.9 \pm 10.3(16)$ & $15.4 \pm 5.8$ & 0.214 \\
\hline$\Delta$ week 10 -baseline & $9.6 \pm 11.9(16)$ & $7.9 \pm 7.0$ & 0.320 \\
\hline
\end{tabular}


weeks on the iron status of indigenous Tarahumara schoolchildren with mild IDA. Our main finding is that, after control for individual variability was attained by using a repeated measurement analysis, $\mathrm{Hb}$ concentration increased by 0.64 $\mathrm{g} / \mathrm{dL}$ and $\mathrm{PF}$ by $2.47 \mathrm{ng} / \mathrm{mL}$ more in the experimental group than in placebo counterparts, although only the former was statistically significant.

The time frame used to conduct the trial was based on constraints derived mainly from the school calendar. Although indigenous children were supposed to start school at the beginning of September and finish in the middle of December, most came in mid-September and left in early December; therefore, if the time required for initial setup and final measurements of the study is accounted for, it can be seen that 10 weeks of effective follow-up was provided. The fact that children had to leave for Christmas vacation and come back in the middle of January limited the possibility of continuing the trial. Moreover, Garcia et al. [44] had reported the largest PF increase at week 16 , and because we were using a considerably higher ratio of AA to iron, we thought that a 10- to 12-week period would be sufficient to detect the effect.

Garcia et al. [44] failed to achieve a positive effect on iron status (experimental vs control: baseline $\mathrm{Hb} 13.7$ vs $13.9 \mathrm{~g} / \mathrm{dL}$ and PF 6.4 vs $6.2 \mathrm{ng} / \mathrm{mL}$; after 8 months, Hb 14.0 vs $13.7 \mathrm{~g} / \mathrm{dL}$ and PF 9.0 vs $8.7 \mathrm{ng} / \mathrm{mL}$ ) with administration of AA in the form of limeade to ID nonanemic adult women. The differences between the studies likely explain the differing results. Although previous investigators had included only subjects with mild ID (they were not anemic) who received an AA dose of only $50 \mathrm{mg}$ daily, in the present study we included only children with IDA, and we administered a dose that was 4 times higher. Therefore, our study subjects were more prone to improvement because iron absorption depends on both initial iron status and the amount of AA in the diet [17,56].

As advised by Garcia et al., our subjects consumed diets with high phytic acid content, supplemented with both AA (guava) and iron (via fortification). The authors also suggested a dietary ratio of 12:1 AA/iron. However, a considerably higher ratio of AA to iron (by weight) has been recommended to increase iron absorption from a meal rich in fortified iron and phytates [5,44,57-60]. At the boarding school level, the ratio reached in the guava group was $\sim 24: 1$ for the main meal (midday), compared with 4:1 in the placebo group. At breakfast and dinner, both groups achieved ratios of $\sim 4-5: 1$. At home, the daily AA/iron ratio was estimated to be $\sim 2-3: 1$ in both groups. Based on the small magnitude of the difference in increased $\mathrm{Hb}$ and $\mathrm{PF}$ concentrations between groups reported in our study, it is probable that even with the 12:1 ratio proposed by Garcia et al., no effect at all would have been achieved, but more research is needed to establish the optimum ratio.

Guava was used in this study because it is one of the few foods with exceptionally high AA content that is available locally at low cost and is tasty and feasible to prepare and consume easily with meals. Fresh raw guavas were utilized because evidence indicates that industrial processing into jam or juice [61], or giving it dried [62], decreases the AA content considerably. Guava is a local product cultivated on a small scale at the bottom of the gorges of the Sierra Tarahumara [63]. Guavas are very much appreciated by the local population for seasonal domestic consumption. Nevertheless, we recognize that the use of electrical devices such as blenders in preparation of the juice complicates such an intervention at the household level in a low-income setting; yet it seems feasible at the school level where, in addition to dry commodities, HI-rich food is offered. Even at the household level, consumption of adequate quantities of guava with the main meal is feasible if people have been informed of its potential impact. However, long-term compliance with this strategy for reducing IDA seems difficult.

We were unable to measure other more sensitive biochemical indicators of iron status such as transferrin receptors [64]. However, PF was used to assess ID because it has been considered a good indicator of ID [55,65]; in addition, we made special efforts to ensure that PF values truly reflected iron stores by excluding children with any history of infection or with a positive CRP test $[66,67]$. Nevertheless, despite a statistically significant improvement in $\mathrm{Hb}$ in the guava group (although of limited clinical importance), the increment in PF concentrations was only marginal compared with placebo. A sample size of 16 subjects per group was calculated in advance to detect differences, but at the end of the study, only 12 individuals in the placebo group were available. Therefore, we cannot rule out the possibility of a type II error. In addition, the superior improvement in $\mathrm{Hb}$ compared with $\mathrm{PF}$ in both groups may reflect the presence of other causes of nutritional anemia such as $B_{12}$ deficiency [40], which is currently being tackled by the school diet alone.

Despite limitations such as small sample size and lack of measurement of more sensitive iron status indicators, this study had some strengths. These include the similarities of studied groups in terms of baseline characteristics and intestinal parasite infections, which were caused mostly by helminths (principally Ascaris lumbricoides) or protozoa (mainly Giardia lamblia) that do not interfere with iron absorption and were treated before the study started. Compliance was high and similar for both groups (guava 90.5\%; placebo 93.6\%; $p=$ 0.38 ); morbidity rates were also comparable. This study started right after the usual 2- to 3-month summer vacation period, during which children had been eating the household diet, which likely depleted some children's iron stores sufficiently to affect $\mathrm{Hb}$ concentrations. Thus, when they entered the study and started to eat a moderately bioavailable diet with higher caloric, protein, iron (including $\mathrm{HI}$ ), and AA intake, the iron status of both groups was likely to improve.

As anticipated, nutrient intake was higher (in general by $50 \%-70 \%)$, including iron intake $(20 \%-30 \%$ higher), in the 
boarding school diet than in the household diet. Yet the children's dietary intake did not differ statistically between groups at the school or in the household. Even though the household diet contained on average more dietary iron than the school diet per $1000 \mathrm{kcal}$ (15.3 vs $12.1 \mathrm{mg}$ ), the mean daily caloric intake was considerably lower at home ( $\sim 1300$ vs 2000 kcal), thus overall iron intake was higher at school ( $\sim 25$ vs 20 $\mathrm{mg}$ ). The iron content of both household and school diets appears high compared with the $6 \mathrm{mg} / 1000 \mathrm{kcal}$ documented in the Western diet $[68,69]$, pointing toward a possible overestimation. This is especially true for the household diet, where the accuracy and precision of 48-hour recalls can be questioned, both because it is difficult to interview Tarahumara mothers, and because they may not have reported their usual diet accurately. However, our data are consistent with those of other studies that have reported similar iron intakes as in the Tarahumara [5,68]. For the school diet, we used individual food weighing by trained personnel; this approach is much more accurate and reliable than is the use of recall data [70].

Nonetheless, an important limitation relates to our failure to compare dietary data only between guava (17) and placebo (16) children with ID at baseline. This is because we did not know which children were deficient at the beginning of the trial, and because we could not assess the dietary intake of all 95 anemic individuals because of the workload involved, we had to take a sample. As a result, we measured and present dietary data from ID and non-ID children, because presenting results only for those deficient at baseline dramatically shrinks the sample, producing very imprecise estimates.

As it was seen in the children from the placebo group, the school diet alone seemed sufficient to improve the $\mathrm{Hb}$ concentration and to replete the children's iron stores, although it did so rather slowly. From this point of view, the AA given in the guava juice had only a small additive effect on $\mathrm{Hb}$ and $\mathrm{PF}$ concentrations. Its impact was probably attenuated by the presence of $\mathrm{HI}$ in the same meal, as other authors have noted [71,72]. The approach we used in this study could have led to different results if the home diet had been utilized instead, but it would have been ethically questionable to exclude the children from the school diet. The feasibility of attempting to carry out such a trial at the household level in this area is questionable because of serious logistical difficulties.

\section{CONCLUSION}

Guava juice used as a source of AA demonstrated marginal beneficial effects of small clinical significance on $\mathrm{Hb}$ and $\mathrm{PF}$ concentrations of indigenous children with IDA fed diets rich in NHI and phytic acid. We suggest that further research is needed to examine the impact of foods this high in AA on diets lacking HI. On its own, however, this study is inadequate to question accepted limitations, including poor long-term compliance except for animal sources, with food-based strategies designed to treat individuals with ID/IDA at the community level.

\section{ACKNOWLEDGMENTS}

The authors are grateful to the Tarahumara schoolchildren and their mothers for their participation and to the personnel at the CDI schools for their assistance with the fieldwork. We especially thank Elvira Castro Moreno, Diana Haydeé Flores Valadéz, Luz María Aguilera Hernández, Maritere Castro Varela, Berenice Herrera Aguilar, and Jesús Alfredo Alvarado Díaz for their collaboration during data collection.

\section{REFERENCES}

1. Hurrell RF: Bioavailability of iron. Eur J Clin Nutr 51:S4-S8, 1997.

2. Hurrell RF, Reddy MB, Juillerat M, Cook JD: Meat protein fractions enhance nonheme iron absorption in humans. J Nutr 136:2808-2812, 2006.

3. Mendoza C, Viteri FE, Lönnerdal B, Young KA, Raboy V, Brown $\mathrm{KH}$ : Effect of genetically modified, low-phytic acid maize on absorption of iron from tortillas. Am J Clin Nutr 68:1123-1127, 1998.

4. Reddy MB, Hurrell RF, Cook JD: Estimation of nonheme-iron bioavailability from meal composition. Am J Clin Nutr 71:937943, 2000.

5. Zimmermann MB, Chaouki N, Hurrell RF: Iron deficiency due to consumption of a habitual diet low in bioavailable iron: a longitudinal cohort study in Moroccan children. Am J Clin Nutr 81:115-121, 2005.

6. Rosado JL, López P, Morales M, Munoz E, Allen LH: Bioavailability of energy, nitrogen, fat, zinc, iron and calcium from rural and urban Mexican diets. Br J Nutr 68:45-58, 1992.

7. Rosado JL, Bourges H, Saint-Martin B: Vitamin and mineral deficiency in Mexico: a critical review of the state of the art. Salud Publica Mex 37:130-139, 1995.

8. Hallberg L, Brune M, Rossander L: Effect of ascorbic acid on iron absorption form different types of meals: studies with ascorbic-rich foods and synthetic ascorbic acid given in different amounts with different meals. Hum Nutr Appl Nutr 40:97-113, 1986.

9. Uzel C, Conrad ME: Absorption of heme iron. Semin Hematol 35:27-34, 1998.

10. Gleerup A, Rossander-Hulthen L, Gramatkovski E, Hallberg L: Iron absorption from the whole diet: comparison of the effect of two different distributions of daily calcium intake. Am J Clin Nutr 61:97-104, 1995.

11. Reddy MB, Cook JD: Effect of calcium intake on nonheme-iron absorption from a complete diet. Am J Clin Nutr 65:1820-1825, 1997.

12. Hallberg L, Rossander L, Skanberg AB: Phytates and the inhibitory effect of bran on iron absorption in man. Am J Clin Nutr 45:988-996, 1987. 
13. Hallberg L, Brune M, Rossander L: Iron absorption in man: ascorbic acid and dose-dependent inhibition by phytate. Am J Clin Nutr 49:140-144, 1989.

14. Tuntawiroon M, Sritongkul N, Brune M, Rossander-Hultén L, Pleehachinda R, Suwanik R, Hallberg L: Dose-dependent inhibitory effect of phenolic compounds in foods on nonhemeiron absorption in men. Am J Clin Nutr 53:554-557, 1991.

15. Siegenberg D, Baynes RD, Bothwell TH, Macfarlane BJ, Lamparelli RD, Car NG, MacPhail P, Schmidt U, Tal A, Mayet F: Ascorbic acid prevents the dose-dependent inhibitory effects of polyphenols and phytates on nonheme-iron absorption. Am J Clin Nutr 53:537-541, 1991.

16. Gregory JF: Ascorbic acid bioavailability in foods and supplements. Nutr Rev 51:301-309, 1993.

17. Hallberg L: Iron and vitamins. Bibl Nutr Dieta 52:20-29, 1995.

18. Wollenberg P, Rummel W: Dependence of intestinal iron absorption on the valency state of iron. Arch Pharmacol 336:578-582, 1987

19. Hallberg L, Rossander-Hulten L, Brune M, Gleerup A: Calcium and iron absorption: mechanism of action and nutritional importance. Eur J Clin Nutr 46:317-327, 1992.

20. Mao X, Yao G: Effect of vitamin $\mathrm{C}$ supplementation on iron deficiency anemia in Chinese children. Biomed Environ Sci 5:125129,1992

21. Davidsson L, Walczyk T, Zavaleta N, Hurrell R: Improving iron absorption from a Peruvian school breakfast meal by adding ascorbic acid or Na2EDTA. Am J Clin Nutr 72:283-287, 2001.

22. Nogueira de Almeida CA, Dutra-De-Oliveira JE, Crott GC, Cantolini A, Ricco RG, Del Ciampo LA, Baptista ME: Control of iron-deficiency anaemia in Brazilian preschool children using iron-fortified orange juice. Nutr Res 23:27-33, 2003.

23. Shah M, Griffin IJ, Lifschitz CH, Abrams SA: Effect of orange and apple juices on iron absorption in children. Arch Pediatr Adolesc Med 157:1232-1236, 2003.

24. Levine M, Rumsey SC, Daruwala R, Park JB, Wang Y: Criteria and recommendations for vitamin C intake. JAMA 281:14151423,1999

25. Bass WT, Malati N, Castle MC, White LE: Evidence for the safety of ascorbic acid administration to the premature infant. Am J Perinatol 15:133-140, 1998.

26. Rivers JM: Safety of high-level vitamin C ingestion. Int J Vitam Nutr Res Suppl 30:95-102, 1989.

27. Meyers DG, Maloley PA, Weeks D: Safety of antioxidant vitamins. Arch Intern Med 156:925-935, 1996.

28. Johnston CS: Biomarkers for establishing a tolerable upper intake level for vitamin C. Nutr Rev 57:71-77, 1999.

29. Curhan GC, Willet WC, Rimm EB, Stampfer MJ: A prospective study of the intake of vitamins $\mathrm{C}$ and B6, and the risk of kidney stones in men. J Urol 155:1847-1851, 1996.

30. Curhan GC, Willet WC, Speizer FE, Stampfer MJ: Intake of vitamins B6 and $\mathrm{C}$ and the risk of kidney stones in women. J Am Soc Nephrol 10:840-845, 1999.

31. Cook JD, Watson SS, Simpson KM, Lipschitz DA, Skikne BS: The effect of high ascorbic acid supplementation on body iron stores. Blood 64:721-726, 1984.

32. Bendich A, Cohen M: Ascorbic acid safety: analysis of factors affecting iron absorption. Toxicol Lett 51:189-201, 1990.
33. U.S. Department of Agriculture, Agricultural Research Service: "Nutrient Database for Standard Reference," Release 18. Washington, DC: USDA, 2007.

34. Hallberg L, Rossander L, Persson H, Svahn E: Deleterious effects of prolonged warming of meals on ascorbic acid content and iron absorption. Am J Clin Nutr 39:577-581, 1984.

35. Food and Nutrition Board, Institute of Medicine: "Dietary Reference Intakes for Vitamin A, Vitamin K, Arsenic, Boron, Chromium, Copper, Iodine, Iron, Manganese, Molybdenum, Nickel, Silicon, Vanadium, and Zinc." Washington, DC: National Academy Press, 2001.

36. Wilson CW: Guava. In Nagy S, Shaw PE (eds): "Tropical and Sub-Tropical Fruits: Composition, Properties, and Uses." Westport, CT: AVI Pub Co, pp 279-299, 1980.

37. Morton J: Guava. In Morton JF (eds): "Fruits of Warm Climates." Miami: Creative Resources Inc, pp 356-363, 1987.

38. Food and Agriculture Organization of the United Nations/ LATINFOODS: Tabla de composición de alimentos de América Latina. Organización de las Naciones Unidas para la Agricultura y la Alimentación. Lima, Peru: Oficina Regional para América Latina y el Caribe, 2000.

39. World Health Organization: "Nutritional Strategies for Overcoming Micronutrient Malnutrition." Document EB89/27. Geneva, Switzerland: WHO, 1991.

40. Monárrez-Espino $\mathrm{J}$, Martínez $\mathrm{H}$, Martinez $\mathrm{V}$, Greiner $\mathrm{T}$ : Nutritional assessment of Tarahumara children at indigenous boarding schools. Eur J Clin Nutr 58:532-540, 2004.

41. Food and Agriculture Organization of the United Nations/World Health Organization: "International Conference on Nutrition: World Declaration and Plan of Action for Nutrition." Rome: FAO/WHO, 1992.

42. Gillespie S: "Major Issues in the Control of Iron Deficiency." Ottawa: The Micronutrient Initiative, 1998.

43. Gibson SA: Iron intake and iron status of preschool children: associations with breakfast cereals, vitamin $\mathrm{C}$ and meat. Public Health Nutr 2:521-528, 1999.

44. Garcia OP, Diaz M, Rosado JL, Allen L: Ascorbic acid from lime juice does not improve iron status on iron-deficient women in rural Mexico. Am J Clin Nutr 78:267-273, 2003.

45. Comisión Nacional para el Desarrollo de los Pueblos Indígenas de México (CDI): "Reglas de Operación del 2008 de los Programas de la CDI." Ciudad de México: Diario Oficial de la Federación, pp $17-24,2007$.

46. Instituto Nacional de Estadística Geografía e Informática: "Censo General de Población y Vivienda 2000: Tabulados Básicos y Síntesis de Resultados por Entidad Federativa: Chihuahua, México." Ciudad de México: INEGI, 2005.

47. Cohen JH, Haas JD: Hemoglobin correction factors for estimating the prevalence of iron deficiency anemia in pregnant women residing at high altitudes in Bolivia. Pan Am J Public Health 6:392-399, 1999.

48. Dallman P, Looker A, Johnson C, Carroll M: Influence of age on laboratory criteria for the diagnosis of iron deficiency anemia and iron deficiency in infants and children. In Hallberg L, Asp N (eds): "Iron Nutrition in Health and Disease." London: John Libbey, pp 65-74, 1996.

49. Gillooly M, Bothwell TH, Torrance JD, MacPhail AP, Derman DP, Bezwoda WR, Mills W, Charlton RW, Mayet F: The effects of 
organic acids, phytates and polyphenols on the absorption of iron from vegetables. Br J Nutr 49:331-342, 1983.

50. Rutishauser IHE, Black AE: Measuring food intake. In Gibney M, Vorster H, Kok FJ (eds): "Introduction to Human Nutrition." The Nutrition Society Textbook Series. Oxford, UK: Blackwell Publishing, pp 225-248, 2002.

51. Monárrez-Espino J, Béjar GI, Vázquez-Mendoza G: Adequacy of the diet served to Tarahumara children in indigenous boarding schools of northern Mexico. Salud Publica Mex 52:25-31, 2010.

52. Wyatt CJ, Triana-Tejast A: Soluble and insoluble Fe, Zn, Ca, and phytates in foods commonly consumed in northern Mexico. J Agric Food Chem 42:2204-2209, 1994.

53. Willet W: "Nutritional Epidemiology." Oxford, England: Oxford University Press, 1998.

54. Centers for Disease Control and Prevention: "Criteria for Anemia in Children and Childbearing Age Women." Report No. 38. Atlanta, GA: CDC, 1989.

55. Worwood M: Ferritin. Blood Rev 4:259-269, 1990.

56. Cook J, Baynes R, Skikne B: Iron deficiency and the measurement of iron status. Nutr Res Rev 5:189-202, 1992.

57. Hurrell RF: Fortification: overcoming technical and practical barriers. J Nutr 132:806S-812S, 2002.

58. Lynch S: Food iron absorption and its importance for the design of food fortification strategies. Nutr Rev 60:S3-S6, 2002.

59. Hurrel RF: Phytic acid degradation as a means of improving iron absorption. Int J Vitam Nutr Res 74:445-452, 2004.

60. Hoppe M, Hulthén L, Hallberg L: The importance of bioavailability of dietary iron in relation to the expected effect from iron fortification. Eur J Clin Nutr 62:761-769, 2008.

61. Jawaheer B, Goburdhun D, Ruggoo A: Effect of processing and storage of guava into jam and juice on the ascorbic acid content. Plant Foods Hum Nutr 58:1-12, 2003

62. Uddin MS, Goburdhun D, Ruggoo A: Degradation of ascorbic acid in dried guava during storage. J Food Eng 51:21-26, 2002.
63. Gobierno del Estado de Chihuahua: Centro de Información Económica y Social, 1999. Accessed at: www.chihuahua.gob. mx/Monografias_Mpios

64. Skikne BS, Flowers CH, Cook JD: Serum transferrin receptor: a quantitative measure of tissue iron deficiency. Blood 75:18701890, 1990.

65. Cook JD, Baynes RD, Skikne BS: Iron deficiency and the measurement of iron status. Nutr Res Rev 5:189-202, 1992.

66. Birgegård G, Hallgren R, Killander A, Stromberg A, Benge P, Wilde L: Serum ferritin during infection. Scand J Haematol 21:333-340, 1978.

67. Worwood M: Serum ferritin. Crit Rev Clin Lab Sci 10:171-204, 1979.

68. Food and Agriculture Organization of the United Nations: "Food Balance Sheets and per Capita Food Supplies (1967-1977)". Rome: FAO, 1980.

69. Food and Agriculture Organization of the United Nations/World Health Organization: "Requirements of Vitamin A, Iron, Folate and Vitamin B12." Nutrition Series No. 23. Rome: FAO, pp 3350, 1988.

70. Bingham SA: Limitations of the various methods for collecting dietary intake data. Ann Nutr Metab 35:117-127, 1991.

71. Layrisse M, Martinez-Torres C, González M: Measurement of the total daily dietary iron absorption by the extrinsic tag model. Am J Clin Nutr 27:152-162, 1974.

72. Cook JD, Monsen ER: Food iron absorption in human subjects. III. Comparison of the effect of animal proteins on nonheme iron absorption. Am J Clin Nutr 29:859-867, 1976.

Received September 11, 2009; revision accepted November 4, 2010. 